\title{
A fókuszhelyzet szerepe erősen reflektáló anyag egyimpulzusos, lézersugaras fúrásakor
}

\section{The Role of Focus Position in Single Pulse Laser Drilling of Highly Reflecting Materials}

\author{
Meszlényi György, ${ }^{1}$ Bitay Enikö² \\ ${ }^{1}$ Óbudai Egyetem, Budapest, Magyarország, meszlenyi.gyorgy@kvk.uni-obuda.hu \\ ${ }^{2}$ Sapientia Erdélyi Magyar Tudományegyetem, Marosvásárhelyi Kar, Gépészmérnöki Tanszék, Marosvásárhely, \\ Románia,ebitay@ms.sapientia.ro
}

\begin{abstract}
The laser processing of materials which are highly reflective at laser wavelengths is problematic. We have to take into account that only a small part of the energy is absorbed, the main part being reflected. In this article we examine the laser processing of highly reflective copper and silver at $1070 \mathrm{~nm}$ wavelength. In laser drilling of printed circuit boards it is necessary to drill copper layer as well. In highly reflecting materials we can drill smaller holes because of the low energy effi-ciency. Naturally in single pulse laser drilling the focus position plays a key role: at the focal spot of the laser beam smaller diameter holes are produced, further from the focal spot, higher diameter holes are produced.
\end{abstract}

Keywords: laser drilling, focal position, highly reflecting materials.

\section{Összefoglalás}

A megmunkáló lézer hullámhosszán erősen reflektáló anyagok megmunkálásakor tekintetbe kell venni, hogy az energia csak kis része hasznosul, a többi visszaverődik. Jelen esetben az $1070 \mathrm{~nm}$-es hullámhoszszon a réz és az ezüst számít ilyen anyagnak. A nyomtatott áramköri lemezek fúrásakor a rézréteget is át kell fúrni. Sokszor előnyös, hogy az erősen reflektáló anyagba kisebb furatokat lehet készíteni éppen a rossz energiahasznosítás miatt. Természetesen az egyimpulzusos, lézersugaras fúráskor a fókuszpozíciónak is nagy szerepe van: a fókuszált lézernyaláb fókuszában lehet a legkisebb, tőle távolodva nagyobb átmérőjü furatokat készíteni.

Kulcsszavak: lézersugaras fúrás, fókuszpozíció, erősen reflektáló anyagok.

\section{Bevezetés}

A lézersugaras fúrás szakirodalma megkülönböztet egyimpulzusos fúrást, illetve ütve fúrást, ahol a lézer egy furat kialakításához több impulzust használ, továbbá a nagyobb furatok létrehozásához használt trepanációs (lépcsős) fúrást és a bolygófúrást [1]. Ebben a cikkben az egyimpulzusos fúrást fogjuk vizsgálni. Nyomtatott áramköri lemezek lézersugaras fúrásánál a réz vezetőréteget is át kell fúrni [2]. Cikkünkben is réz- és ezüstfólia fúrását vizsgáljuk.

\section{A megmunkáló lézer tulajdonságai}

A kísérletekhez használt lézer IPG-gyártmányú, 150/1500-QCW-AC típusú szállézer volt, amelynek műszaki adatait az 1. táblázat tartalmazza.

Megtévesztő a $150 \mathrm{~W}$ átlagteljesítmény, mert ha egy impulzus teljesítményét kiszámítjuk, az impulzusenergiát elosztva az impulzusidővel, akkor meglepően nagy értéket kapunk: Pl. $P_{p}=E_{p} / t_{p}=$ $15 \mathrm{~J} / 0,01 \mathrm{~s}=1500 \mathrm{~W}$ impulzusteljesítmény adódik ezekből az értékekből. Ez azt is jelenti, hogy az emberi szem számára egy $150 \mathrm{~W}$ átlagteljesítményü impulzuslézer veszélyesebb, mint egy 
1. táblázat. $A z I P G$ gyártmányú, 150/1500-QCW-AC típusú, itterbium-YAG szállézer müszaki adatai

\begin{tabular}{|l|l|}
\hline Hullámhossz & $1070 \mathrm{~nm}$ \\
\hline Maximális átlagteljesítmény & $150 \mathrm{~W}$ \\
\hline Maximális impulzusteljesítmény & $1500 \mathrm{~W}$ \\
\hline Maximális impulzusenergia & $15 \mathrm{~J}$ \\
\hline Impulzusidő & $0,05-50 \mathrm{~ms}$ \\
\hline Impulzusfrekvencia & $10-50 \mathrm{kHz}$ \\
\hline $\mathrm{M}^{2}$ faktor & 1,05 \\
\hline
\end{tabular}

folyamatos üzemű $150 \mathrm{~W}$-os lézer, ezért a szemet az adott hullámhosszon védő és megfelelő optikai sűrűségű védőszemüveggel kell védeni.

\section{A fókuszált lézernyaláb meghatáro- zó változóinak elemzése}

Lézersugaras, egyimpulzusos fúrásnál fontos szerep jut a megmunkálólézernek, ezen belül a fókuszált nyaláb keresztmetszeti jellemzőjének, a fókuszfoltátmérőnek, mert a fókuszált nyaláb az az érintésmentesen dolgozó szerszám, mely energiaátadás útján a megmunkálást végzi.

Az optikai szálból kilépő lézernyaláb átmérője 14 mikrométer $\left(\mathrm{d}_{1}\right)$. A kilépő nyalábot tágító és párhuzamosító kollimátorlencse fókusztávolsága $50 \mathrm{~mm}\left(\mathrm{f}_{1}\right)$. A párhuzamos lézernyalábot a munkadarabra fókuszáló lencse fókusztávolsága $50 \mathrm{~mm}\left(\mathrm{f}_{2}\right)$. A nyalábtágító állása 1-es volt, így a nyalábtágítási faktor (Be) szorzótényezője 1. Ezen adatok alapján kiszámolható a fókuszált lézernyaláb fókuszfoltátmérője $\left(\mathrm{d}_{2}\right)$ az alábbi képlettel [3]:

$$
d_{2}=\frac{4 \lambda M^{2} f_{2}}{d_{3} \pi}
$$

Az egyenletből 14 mikrométer adódik a fókuszált lézernyaláb fókuszátmérőjének. Ez, összehasonlítva a korábbi cikkünkben [4] használt Nd:YAG lézer 81 mikrométeres, nyalábtágítás nélküli foltméretével, rendkívül kis érték, ami azt jelenti, hogy a lézer energiája nagyon kis területre fókuszálható, tehát nagy energiasűrűség érhető el. Vágásnál ez kisebb vágási rést és vastagabb vágható anyagot jelent. Az eltérés a két lézer különböző működési elvéből fakad, ami a nyalábminőségi tényezőt befolyásolja. Míg a korábbi cikkünkben használt Nd:YAG lézer nyalábminőségi tényezője $\mathrm{M}^{2}=3-5$, addig a szállézeré 1,05. Miért fontosak ezek az értékek?
A fókuszált lézernyaláb foltátmérőjének másik képletéből (2) következik, hogy minél kisebb az M2 tényező értéke, annál kisebb területre fókuszálható a lézer energiája [5].

$$
d_{2}=\frac{d_{1} f_{2}}{f_{1} B_{e}}
$$

A képletben szereplő $d_{3}$ a párhuzamos lézernyaláb fókuszáló lencse előtti átmérője, amely a többi tényező ismeretében számítható, 5,11 mm-nek adódik. A lézer hullámhosszának $(\lambda)$ szerepe: ha itterbium-szállézert ( $\lambda=1,070$ mikrométer) használunk $\mathrm{CO}_{2}$ lézer ( $\lambda=10,600$ mikrométer) helyett, akkor 10-szer kisebb foltra lehet fókuszálni a lézernyalábot.

A Rayleigh-hossz a nyalábterjedés irányában a fókuszsíktól mért az a hossz, amely végén a lézerfolt területe duplájára, így a nyaláb rádiusza gyök kettő-szeresére nő, ezért a felületegységre jutó impulzusenergia a felére esik vissza a fókuszfoltban számíthatóhoz képest. Általában a Rayleigh-hossz kétszeresén belül tekintik fókuszban levőnek a nyalábot. Képlete nagyon hasonló a lézerfoltátmérő képletéhez, csak itt a fókuszáló lencse fókusztávolsága és a lencse előtti nyalábátmérő a négyzeten szerepel (3) [6].

$$
Z_{r}=\frac{4 \lambda M^{2} f_{2}^{2}}{d_{3}^{2} \pi}
$$

A képletbe az eddig megadott adatokat behelyettesítve 137 mikrométer adódik. Természetesen $d_{2}$ és $\mathrm{Z}_{\mathrm{r}}$ értéke tájékoztató jellegü, egyes szakirodalmak például kihagyják $\mathrm{M}^{2}$ faktort a képletből, ami elég furcsa. Ha a nyalábtágító egy zoomos rendszer, akkor a lencsehibák is ronthatnak a fókuszálhatóságon.

A fenti két jellemző értékéből az derül ki, hogy nem biztos, hogy érdemes nyalábtágítót használni, mert a tágítás nélküli 14 mikrométeres foltátmérő elég kis érték, tágítással $\mathrm{d}_{3}$ értékét növelve a fókuszfolt mérete tovább csökken, de $Z_{\mathrm{r}}$ értéke is csökken, tehát a fókuszfolttól a lézersugár terjedésének irányában jobban széttart a nyaláb.

A fentiekben kiszámolt $d_{2}$ és $Z_{r}$ értékek csak a geometriai jellemzőkből származnak, míg azt, hogy a valóságban mekkora térfogatú anyag olvasztható meg egy lézerimpulzussal, vagyis egy impulzus periódusideje alatt átadott energiával, azt két tényező befolyásolja erősen. Az első az, hogy mekkora a lézerimpulzus teljesítménye, amelyet erre a foltméretre koncentrálunk, ez jelen esetben akár 1500 watt is lehet. A másik tényező a megmunkálandó anyag releváns fizikai jellemzőinek összessége: sűrüség, olvadáspont, 
fajhő, olvadáshő, reflexiós tényező a lézer hullámhosszán; ezekre a 4. pontban térünk ki. A lézerberendezést üzemeltető Pulzor Művek tapasztalatai szerint például rozsdamentes acélt $1 \mathrm{~mm}$ vastagságig tud vágni a rendszer, rézötvözetek vágását $0,4 \mathrm{~mm}$ vastagságig [7]; ám ezek a vastagságok túlmennek a kiszámított Rayleigh-hossz kétszeresén.

Az itterbium-szállézert és a munkadarab-mozgató szánokat a Pulzor Művek építette össze, és ugyanő készítette el a rendszer vezérlőprogramját, mely saját CAM-programmal generálja a CAD-fájlból a munkadarab elkészítéséhez szükséges mozgásokat leíró CNC-kódot.

\section{A megmunkált anyagok tulajdonságai}

Miért jelent nagy kihívást a lézersugárzás hullámhosszán erős reflexiót mutató anyagok fúrása? Az minden lézeres megmunkálásnál meghatározó jelentőségű, hogy az anyag felületére beeső sugárzás - és az általa szállított energia, illetve teljesítmény - egy része visszaverődik, másik része elnyelődik, míg egy harmadik része áteresztődik, tehát [8]:

$$
P_{1}=P_{2}+P_{3}+P_{4}
$$

Itt $\mathrm{P}_{1}$ az összes, $\mathrm{P}_{2}$ a visszavert, $\mathrm{P}_{3}$ az elnyelt, $\mathrm{P}_{4}$ az áteresztett energiából számítható teljesítményt jelöli. Tömbi anyagok megmunkálásánál elhanyagolható az áteresztett energia, tehát minél nagyobb energiahányad reflektálódik, annál kevesebb teljesítmény hasznosul. $\mathrm{Ha} \mathrm{P}_{1}=1$, akkor $\mathrm{P}_{3}$ az abszorpciós tényező (a), $\mathrm{P}_{2}$ a reflexiós tényező ( $\mathrm{r}$ ) adott anyagra és adott hullámhosszra vonatkozóan. A lézersugárzás hullámhosszán erősen reflektáló anyagoknál az anyag felületére érkező lézerimpulzus energiájának nagy része visszaverődik, és csak a maradék hasznosul (ld. 2. táblázat).

A korábbi kísérletünkben [4] 1.4304 minőségű rozsdamentes acélt használunk. A 2. táblázat alapján megjósolható, hogy az ehhez képest sokkal erősebben reflektáló ezüstöt és rezet nehezebb megmunkálni. Most derül majd ki, hogy a

2. táblázat. A megmunkált anyagok abszorpciós (a), és reflexiós (r) adatai 1064 nanométer hullámhosszon

\begin{tabular}{|l|c|c|}
\hline \multicolumn{1}{|c|}{ Anyag } & a & r \\
\hline Rozsdamentes acél [9] & 0,31 & 0,69 \\
\hline Ezüst [10] & 0,03 & 0,97 \\
\hline Vörösréz [10] & 0,04 & 0,96 \\
\hline
\end{tabular}

rendkívül kicsire fókuszált lézerfolt okozta nagy teljesítménysűrüség előnyt jelent-e. Problémát okozhat az is, hogy a visszavert lézersugárzás visszajut a lézerbe, ott károsodást okozva [11]. A kísérletek során a lézerfej függőleges volt, alatta a próbadarabokat a vízszintessel bezárt $8^{\circ}$-os szögben feszítettük ki, így a beesési és visszavert sugárzás 16 fokot zárt be, tehát közvetlenül nem jutott vissza sugárzás a lézerbe.

\subsection{A kísérleti munka}

A kísérletnél használt réz- és ezüstfóliáknak a lézerfej alatti vízszinteshez mért, adott szögű kifeszítéséhez készüléket terveztünk, mely a szinusz-emelő elvén működik. A készülékben a fólia szöge mérőhasábbal állítható. A 17,5 mm-es mérőhasáb-beállításhoz a vízszintessel bezárt 8,11ํos szög tartozik. A lézerre szerelt készülék

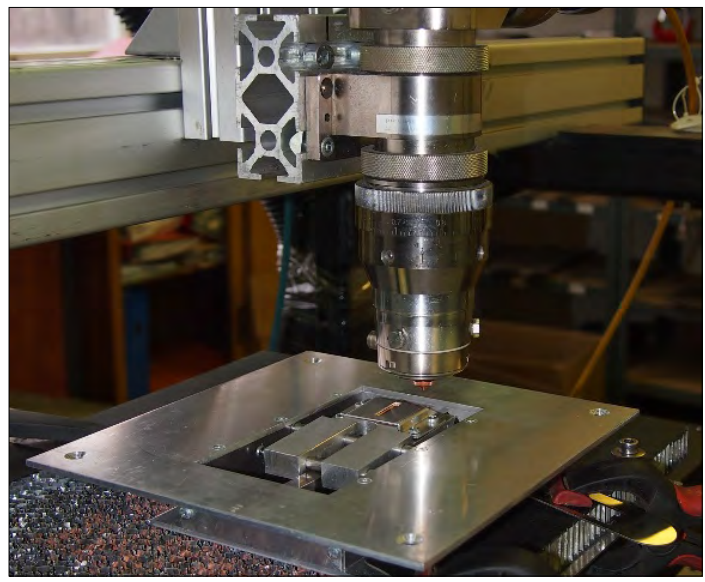

1. ábra. A mérőhasábbal állítható fóliafeszítő a lézerfej alatt

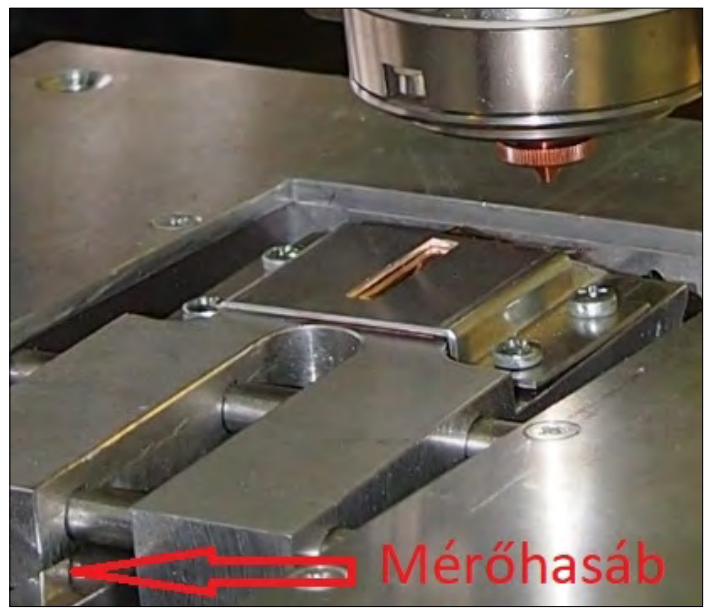

2. ábra. A fóliafeszítő közelebbről 
az 1. ábrán látható.

A közös kísérleti beállítások a következők voltak:

- fókuszállás a lézerfejen: -2,6 mm;

- munkagáz: nitrogén 5 bar nyomáson.

\section{A rézfólián végzett fúrási kísérletek}

50 mikrométer vastag rézfólia fúrását végeztük különböző energiájú lézerimpulzusokkal. Beállítottuk az impulzusidőt állandó értékre, 0,2 ms-ra. Változtattuk a teljesítményszintet $60-80 \%$ között; ez meghatározta a kijelzett impulzusteljesítményt. Számítottuk az impulzusenergiát, mely az impulzusteljesítmény és az impulzusidő szorzata. Tehát az összetartozó kísérleti változók, melyekkel egy furatsor készült, a 3. táblázatban láthatók.

A 3. ábrán a rézfólia furatai láthatók mikroszkóp alatt, hátsó megvilágításban a kép alja a lézerfejhez közelebbi régiót ábrázolja. A jobbról balra növekvő impulzusteljesítmény a fúvókához egyre közelebb lyukaszt. A furatok a kép tetején a kis sebesség és az állandó impulzusfrekvencia miatt egymásba érnek. A rögzített lézerfejhez képest $10 \mathrm{~mm} / \mathrm{s}^{2}$ mozgató rendszer gyorsulást és $20 \mathrm{~mm} / \mathrm{s}$ mozgatási sebességet állítottuk be. A mikroszkópos mérésnél a furatok változó távolságát is mérni kellett a lézersugár terjedési irányába eső, függőleges $\mathrm{Z}$ koordináta számításához.

A 4. ábra az olvasztási határenergia, és a fókuszált nyaláb kölcsönhatását ábrázolja. A fókuszfolttól távol nagyon szétterül a nyaláb, itt már nem elég a felületegységre jutó energia az anyag átolvasztásához. Ilyen furatkezdeményt mutat az 5. ábra.

A 4. ábra és a 8. ábra furataira a Z koordináta függvényének régiói összepárosíthatók:

- 2. régió: A maximálisnál kisebb furatok: itt a nyaláb energiaeloszlása éppen metszi az olvasztási határt.

3. táblázat. Rézfólia fúrási kísérleténél soronként egy furatsorozathoz tartozó impulzusadatok

\begin{tabular}{|c|c|c|}
\hline $\begin{array}{c}\text { Impulzusidő } \\
\text { (ms) }\end{array}$ & $\begin{array}{c}\text { Impulzusenergia } \\
\text { (mJ) }\end{array}$ & $\begin{array}{c}\text { Impulzusteljesít- } \\
\text { mény (W) }\end{array}$ \\
\hline 0,2 & 198 & 989 \\
\hline 0,2 & 213 & 1067 \\
\hline 0,2 & 229 & 1145 \\
\hline 0,2 & 245 & 1225 \\
\hline 0,2 & 259 & 1296 \\
\hline
\end{tabular}

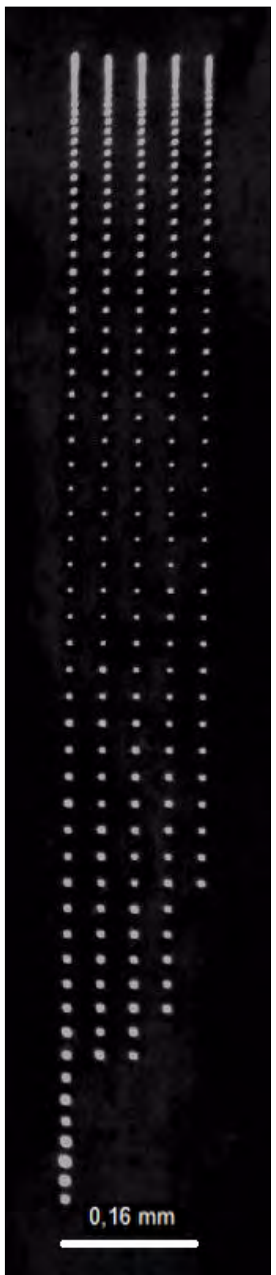

3. ábra. Rézfólia furatairól készített mikroszkópi kép hátsó megvilágításban

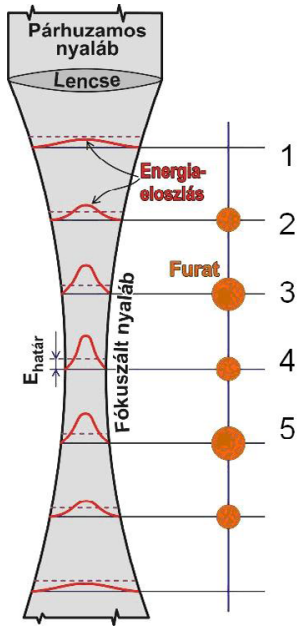

4. ábra. Az olvasztási határenergia és a fókuszált nyaláb kölcsönhatása [4] 
- 3. régió: A maximális furatok: itt a nyaláb energiaeloszlása a legnagyobb átmérőt hagyva metszi az olvasztási határt.

- 4. régió: A minimális furatok: itt a nyaláb energiaeloszlása a legkisebb átmérőt hagyva metszi az olvasztási határt, tehát itt van a nyaláb fókusza.

- 5. régió: Ismét nagyobb furatok: a nyaláb energiaeloszlása a nagyobb átmérőt hagyva metszi az olvasztási határt.

A 6. ábrán látható egy, a fúvókához közel eső furat képe, ahol a nitrogéngáz szétfröcskölte az olvadt anyagot: itt nehéz átmérőt meghatározni, mert a furatok kráter alakúak és lefelé szűkülően kúposak. Ez esetben négy zóna különböztethető meg:

1. A legnagyobb kör a hőhatásövezet.

2. Utána következik a megolvadt anyag átmérője.

3. Ezután a furat átmérője a lézerforrás felőli fólia oldalon: ezeket mértük.

4. A legkisebb kör a lemez alján mérhető átmérő: sajnos ebbe a tapadósalak is beárnyékol (ld. 7. ábra).

A fúvókától távolabbi furatoknak (9. ábra) jobbak a kontúrjai és könnyebben mérhetők - bár szabálytalanok, mivel inkább ellipszisre emlékeztetnek. A furatok körül található nagy átmérőjü hőhatásövezet az erősen reflektáló anyag miatt alakult ki: itt nem elég az impulzusenergia az anyag átolvasztásához.

A különböző fókuszhelyzettel létrejövő furatok átmérőjének Z koordinátafüggvénye közel állandó volt, az impulzusadatoktól függetlenül. Ennek oka, hogy az impulzusenergia csak kb. 25\%-kal változott, és a furatok átmérőinek szórása nagy volt (ld. 6. ábra magyarázatát).

\section{Az ezüstfólián végzett kísérletek}

150 mikrométer vastag ezüstfólia fúrását végeztük különböző idejü lézerimpulzusokkal. Beállítottuk az impulzusidőt 0,1 és 0,5 ms között. Beállítottuk a teljesítményszintet 100\%-ra; ez meghatározta a kijelzett impulzusteljesítményt, mely az első adatsor kivételével 1580 watt körül volt. Az ezüstfólia háromszor olyan vastag volt, mint a réz, ezért kellett nagyobb teljesítmény. Számítottuk az impulzusenergiát, mely az impulzusteljesítmény és az impulzus idő szorzata. Tehát az összetartozó kísérleti adatok, melyekkel egy furatsor készült, a 4. táblázatban láthatók.

A 10. ábrán az ezüstfólia furatai láthatók hátsó megvilágításban, a kép alja a lézerfejhez közelebbi régiót ábrázolja. Jobbra az első furatsor alja

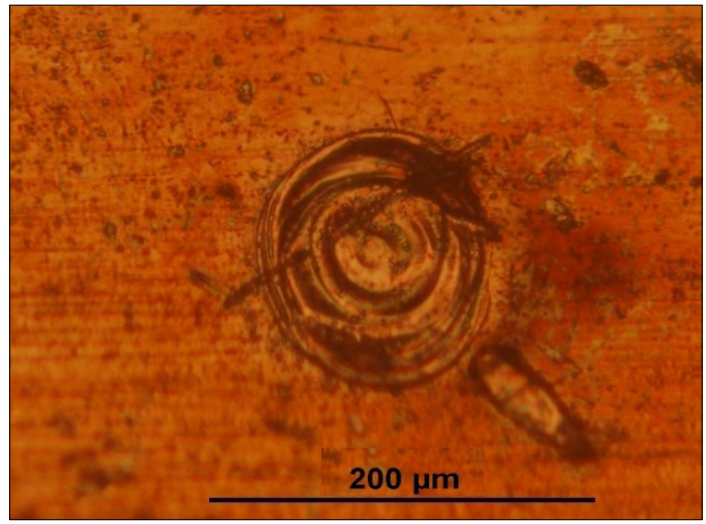

5. ábra. A szétterülő nyaláb miatt itt nem jött létre furat

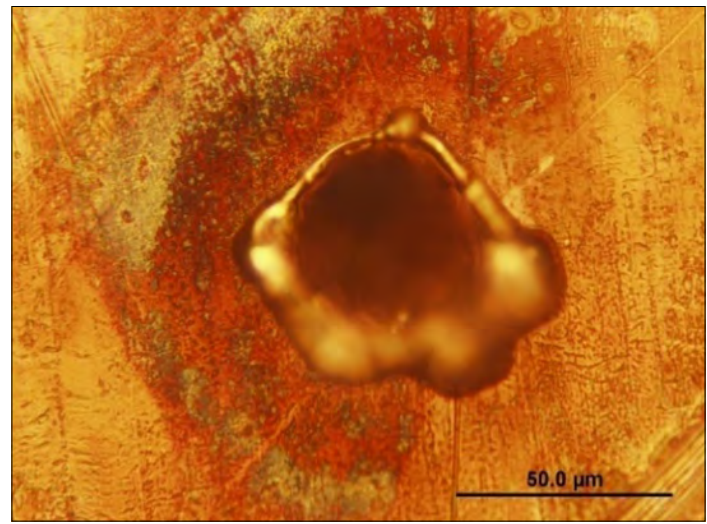

6. ábra. Egy, a fúvókához közeli furat képe

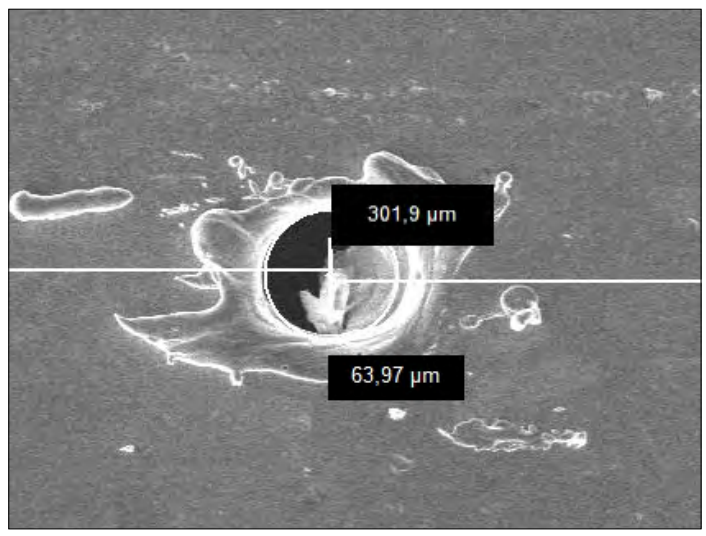

7. ábra. Egy, a fúvókához közeli furat képe, itt látszik a tapadósalak. 301,9 mikrométer a távolság a szomszéd furattól, 63,97 mikrométer a hárompontos furatátmérö-mérés eredménye

hiányzik: itt nincs lyukasztás, mert 7\%-kal kisebb az impulzusteljesítmény. A többi furat képe azonos lefutást mutat, mert állandó az impulzusteljesítmény. 
A furatok a kép tetején és az alján a kis sebesség és az állandó impulzusfrekvencia miatt egymásba érnek. A munkadarab lézerfejhez képesti gyorsulása és sebessége és a Z koordináta korrekciója azonos a rézmintánál ismertetettnél.

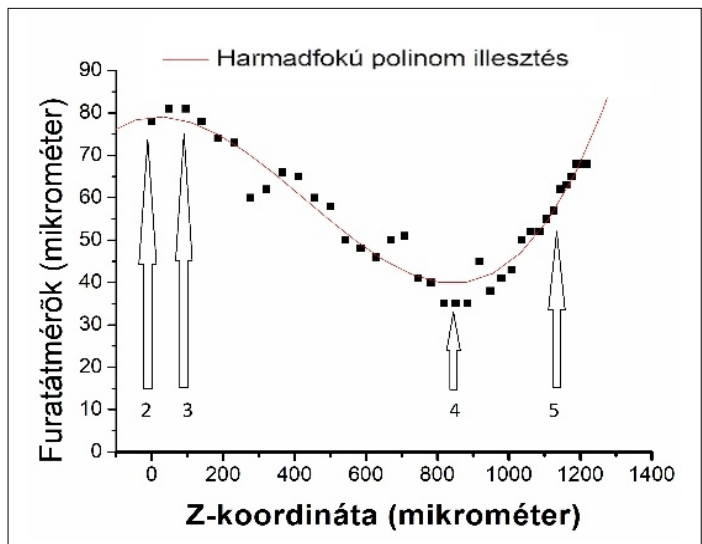

8. ábra. Rézminta 213 mJ impulzusenergiával létrehozott furatainak $Z$ koordinátafüggvénye és annak régiói; $Z=0$ a lézerfejhez közelebbi koordináta

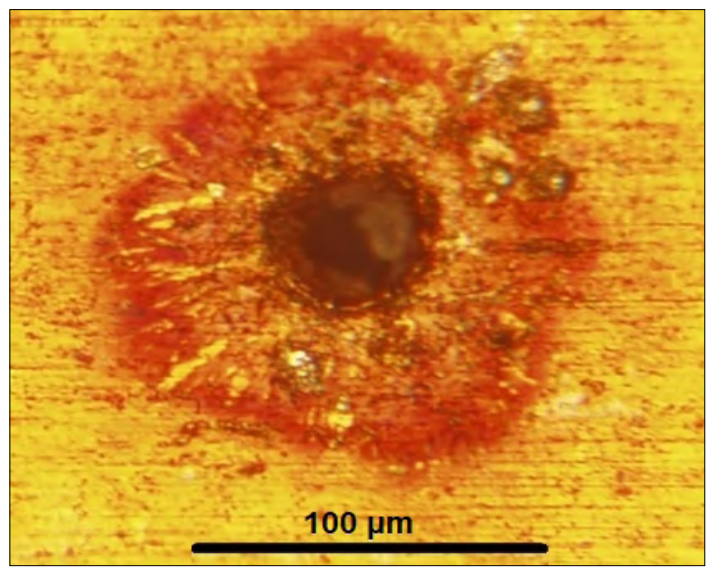

9. ábra. Egy, a fúvókától távolabbi furat

4. táblázat. Az ezüstfólián végzett fúrási kísérletekben választott értékek a lézerimpulzus technológiai változóira nézve

\begin{tabular}{|c|c|c|}
\hline $\begin{array}{c}\text { Impulzusidő } \\
\text { (ms) }\end{array}$ & $\begin{array}{c}\text { Impulzusenergia } \\
\text { (mJ) }\end{array}$ & $\begin{array}{c}\text { Impulzusteljesít- } \\
\text { mény (W) }\end{array}$ \\
\hline 0,1 & 148 & 1481 \\
\hline 0,2 & 317 & 1583 \\
\hline 0,3 & 475 & 1584 \\
\hline 0,4 & 636 & 1589 \\
\hline 0,5 & 792 & 1583 \\
\hline
\end{tabular}

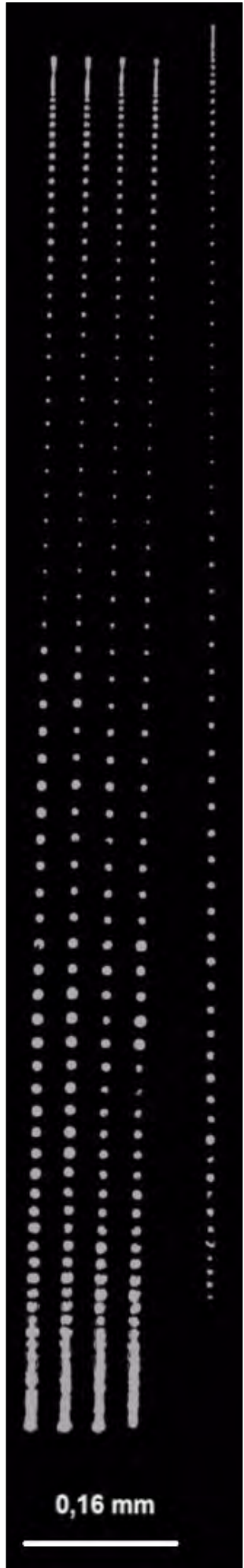

10. ábra. Ezüstfólia furatairól készített mikroszkópi kép hátsó megvilágításban 
A 4. ábra és a 11. ábra furatainak Z koordinátafüggvényének régiói összepárosíthatók: de itt csak a 3., 4. és az 5. régió figyelhető meg a nagyobb impulzusteljesítmény miatt.

A 12. ábrán egy, a fúvókához közeli furat képén olvadt anyag fröcskölési nyoma látszik, mely nehézzé teszi a furatátmérő-mérést, de nem annyira, mint a 6 . ábrán a réznél látszott.

A 13. ábrán két, a fúvókától távoli kontrasztos furat képe látható, itt a hőhatásövezet kevésbé látszik, mint a réznél.

A 11. ábra tartalmazza a létrejött furatok átmérőit a lézersugár függőleges terjedési irányába eső Z koordináta szerint. Ezek erős ingadozást mutatnak, mert az összes szilárdtestlézer hátránya, hogy nem adnak egyenletes impulzusokat. Ennek az az oka, hogy nem stacionárius üzemben müködnek [12].

Mivel a fókuszált lézernyaláb foltmérete rendkívül kicsi, így a plazmajelenség is könnyebben létrejön, ez is okozhat szóródást a furatátmérőkben.

Azonban a 11. ábrához hasonlóan a furatátmérők $\mathrm{Z}$ koordinátafüggvénye közel állandó volt, ez azt mutatja, hogy a megmunkálás szempontjából nemcsak pusztán az impulzusenergia számít, hanem az is, hogy azt mennyi idő alatt vittük be, tehát az impulzusteljesítmény. Ez pedig $\mathrm{P}_{\mathrm{P}}=\mathrm{E}_{\mathrm{p}} / \mathrm{t}_{\mathrm{P}}$, ami a kísérlet során állandó volt. A lézersugaras megmunkálás szakirodalma is $\mathrm{W} / \mathrm{cm}^{2}$ felületi teljesítménysűrűség szerint osztályozza a megmunkálásokat.

Ennek ellenére levonható az a következtetés, hogy a furatátmérőkre legerősebben a Z koordináta hat. A lézerrel történő mikromegmunkáláskor ez nem zavaró, mivel ott nagyobb frekvenciával kisebb energiájú impulzusokat adnak le, így az impulzusenergia-eltérések átlagolódnak.

\section{Következtetések:}

A megmunkálólézer hullámhosszán erősen reflektáló anyagok megmunkálásakor tekintetbe kell venni, hogy az energia csak kis része hasznosul, a többi visszaverődik. A 14 mikrométeres fókuszált lézernyaláb fókuszátmérője rendkívül kis érték, ami azt jelenti, hogy a lézer energiája egy nagyon kis területre fókuszálható, tehát nagy energiasürűség érhető el, ez kompenzálja a veszteségeket.

A kísérletekből kiderült, hogy a fókuszpozíciónak a legerősebb a hatása a furatátmérőre, és a furatátmérők $\mathrm{Z}$ koordinátafüggvényei erős ingadozást mutatnak, ennek lehetséges okai:

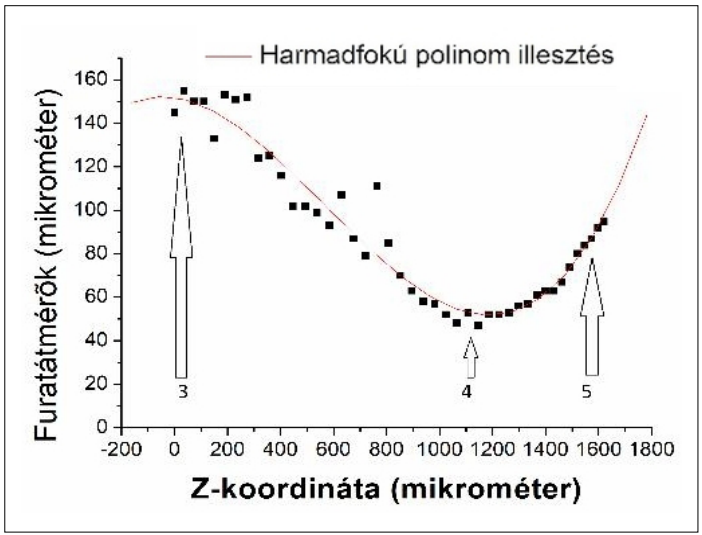

11. ábra. Rézminta $636 \mathrm{~mJ}$ impulzusenergiával létrehozott furatainak $Z$ koordinátafüggvénye, és annak régiói; $Z=0$ a lézerfejhez közelebbi koordináta

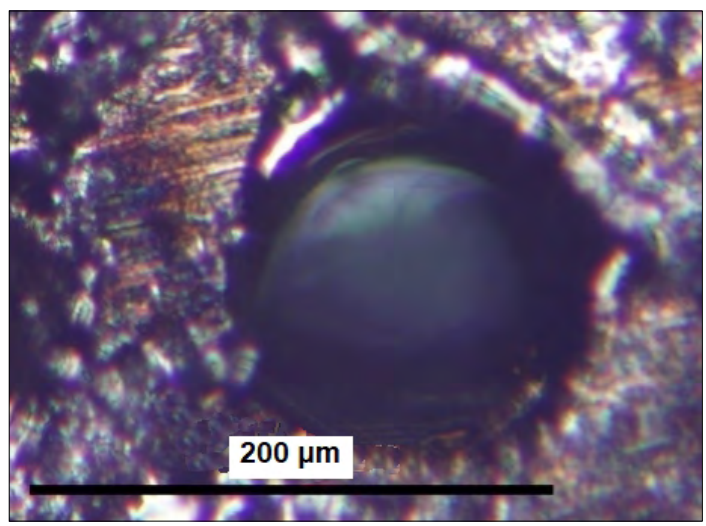

12. ábra. Egy, a fúvókához közeli furat képe, olvadt anyag fröcskölési nyoma látszik

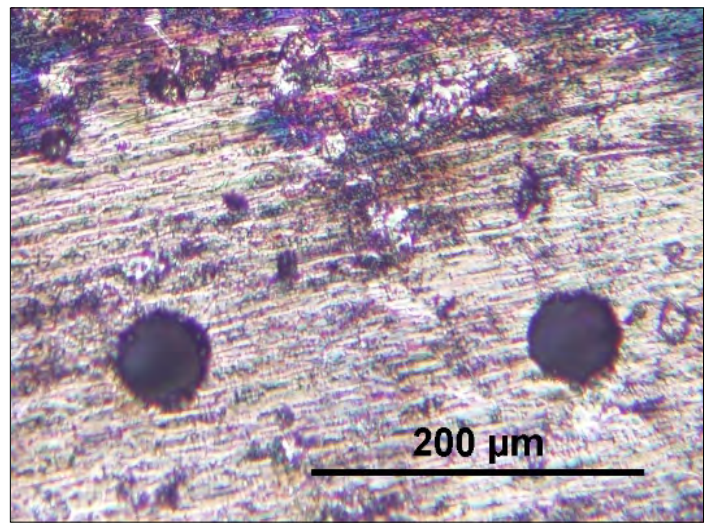

13. ábra. Két, a fúvókától távoli furat képe, itt a hőhatásövezet kevésbé látszik, mint a réznél

- a lézeres fúrásnál olyan nemlineáris hatások lépnek fel, mint a plazmaképződési jelenség és az elpárolgott fém páranyomása; 
- az összes szilárdtest-lézer hátránya, hogy nem adnak egyenletes impulzusokat. Ennek az az oka, hogy nem stacionárius üzemben müködnek.

- kis egyenetlenségek a munkadarabon (50 mikrométer) a furatátmérők 10\%-os változását okozhatják [13]

A jelen kísérletekhez felhasznált szállézer jó nyalábminősége és nagy impulzusteljesítménye miatt még az ilyen nehéz feladatokat is lehetővé teszi, mint az erősen reflektáló anyagok lézersugaras fúrása.

\section{Köszönetnyilvánítás}

A cikk szerzői megköszönik a Pulzor Művek ügyvezetőjének, Puskás Zsoltnak és termelésvezetőjének, Vincze Dávidnak, hogy a megtervezett kísérleteket lehetővé tették és a végrehajtásában segítettek.

\section{Szakirodalmi hivatkozások}

[1] Buza G.: Lézersugaras technológiák II. Edutus Főiskola, Budapest, 2012. 79.

[2] Kurosawa M.: Laser drilling high-density printed circuit boards. (letöltve: 2019. május 28.) https://www.industrial-lasers.com/drilling/ article/16485325/laser-drilling-highdensityprinted-circuit-boards

[3] Xiaodong N.: Laser Welding. Published by Sciyo Janeza Trdine 9, 51000 Rijeka, Croatia, 2010. 54.

[4] Meszlényi Gy., Bitay E.: Az egyimpulzusos lézersugaras fúrás folyamatának elemzése. Bányászati és kohászati lapok, Kohászat, 151/5-6. (2018) 40-44.

[5] Paripás B., Szabó Sz., Kocsisné Baán M., Tolvaj Béláné, Bencs P.: Lézeres mérési- és megmunkálási eljárások a gépészetben. Miskolci Egyetem, Miskolc, 2009. 66.

[6] Alexander F. H. K.: Theoretical analysis of laser beam cutting. Shaker Verlag, Aachen, 2002. 14.

[7] Puskás Zs.: Lézeres mikromegmunkálás szállézerel. (letöltve: 2019. április 17.)

http://docplayer.hu/720391-Lezeres-mikromeg munkalas-szallezerrel.html

[8] Kreisz I.: Lézersugár-vezetés. Edutus Főiskola, Budapest, 2011. 82.

[9] Duley W.: Laser welding, 1. edition. Wiley-Interscience, 1998. 69.

[10] Ready J. F., Farson D.: LIA Handbook of Laser Materials Processing. Laser Institute of America Magnolia Publishing Inc., 2001. 182.

[11] Naeem M.: Laser processing of reflective materials. (letöltve: 2019. május 28.)

https://onlinelibrary.wiley.com/doi/epdf/10.1002/ latj.201390001

[12] Tradowsky K.: A LASER ABC-je. Müszaki Könyvkiadó, Budapest, 1971. 99-100.

[13] Stephen A.: Laser micro drilling methods for perforation of aircraft suction surfaces. Elsevier Science Direct Procedia CIRP 74, 2018. 404. https://doi.org/10.1016/j.procir.2018.08.157 